\title{
Sobre a gestão e digestão da interatividade no contexto da TV digital
}

Cláudio Clécio Vidal Eufrausino

Mestre em comunicação, mídia e cultura pela Universidade Federal de Pernambuco (UFPE). Escolhido como um dos integrantes da publicação "Jovens produtores de mídia” (2006), desenvolvida pela Unesco.

Resumo: O objetivo deste artigo é analisar as possibilidades, conflitos e desafios relativos à interatividade na TV digital. Para isso, busca-se refletir sobre o lugar da TV digital num espaço de estratégias discursivas que dialogam com o gênero discursivo TV e com a convergência multimidiática, em particular na internet.

Palavras-chave: Interatividade, convergência multimidiática, TV digital.

\begin{abstract}
This article intends to analyze the possibilities, conflicts and challenges related to the interactivity on digital TV. To achieve this purpose implies to reflect about the place of digital TV in a discursive strategies space that dialogue with the discursive gender TV and with the multimedia convergence, whose most evident example is the internet.
\end{abstract}

Key-words: Interactivity, multimedia convergence, digital TV.

\section{Preocupações sobre o papel das estratégias enunciativas da TV no contexto de sua digitalização}

O gênero discursivo "Televisão" é orientado por dois tipos diferentes de estratégias enunciativas (FECHINE, 2007: 21). A primeira consiste na tentativa de ocultar os processos envolvidos no fazer televisivo, deixando à mostra somente o produto final, acabado: a paisagem. Esta vertente está associada à produção de um "efeito de realidade" (FECHINE, 2007: 21). Inspirado pelo cinema hollywoodiano, o efeito de realidade é gerado por um "modelo de representação naturalista", por meio do qual as "'histórias são contadas por ninguém e para ninguém' e a tela nada mais é do que uma ‘janela para o real’” (FECHINE, 2007: 21). A outra estratégia enunciativa, num movimento contrário, enfatiza a metalinguagem. Por este caminho, iriam os programas que ao mesmo tempo em que veiculam um determinado conteúdo, falam sobre como se dá o processo de veiculação do referido conteúdo. O procedimento está associado "ao próprio reconhecimento do espectador como um interlocutor, à exibição do aparato de gravação/transmissão ou à inclusão de qualquer referência que nos dê acesso, a partir daquilo que se vê na tela, ao seu próprio fazer-se ético e técnico-estético" (FECHINE, 2007:21).

Uma das preocupações dos pesquisadores, tanto da Comunicação quanto da Engenharia e da Informática, tem sido qual das referidas estratégias enunciativas da TV tradicional será adotada pela TV digital. Ao se discutir as possibilidades e desafios da TV digital, o efeito-realidade e, por consequência, a ideia de que os conteúdos transmitidos pela TV devem seguir a estética asséptica da paisagem, parece predominar sobre a estratégia enunciativa apoiada na metalinguagem. Durante o seminário Televisão Digital: Cenários, 
Modelos, Linguagem, realizado em setembro de 2008, na Universidade Federal de Pernambuco, uma considerável parte das discussões abordava o tema: como fazer com que a TV digital proporcione interatividade sem que pareça que a interatividade está acontecendo? Do modo como se seguiu o debate, elementos característicos da interatividade internáutica, a exemplo da necessidade de conviver com a barra de progresso de downloads e as quedas de conexão, foram considerados persona non grata na TV digital. Neste seminário, várias vozes afirmaram ser inconcebível admitir uma queda do sistema na TV digital. Pesquisadores, a exemplo Carlos Ferraz, do Centro de Estudos e Sistemas Avançados do Recife (Cesar), acreditam que a "tela preta" ou o travamento da transmissão de dados seria responsável por uma frustração de expectativas que desaguaria na ruína do projeto da TV digital. Outros participantes do evento, em concordância com este ponto de vista, afirmam que, para evitar esse e outros riscos da interatividade, a TV digital deveria calibrar-se pelo baixo grau de interatividade, localizada pontualmente na programação e resumida ao acesso a informações adicionais sobre determinados conteúdos. Este tipo de preocupação pode ser resumido nas seguintes questões: como a TV, caracterizada por um fluxo ininterrupto ou total (JAMESON, 1997) de informação e com uma estética, grande parte das vezes, voltada à máxima redução dos ruídos comunicacionais, será capaz de lidar com fenômenos como um possível travamento do sistema ocasionado, por exemplo, por uma sobrecarga interativa? Ou: a plenitude interativa - na qual a audiência está apta a gerar conteúdos televisivos - não marcaria o fim da TV enquanto proposta estético-discursiva? Estas questões dizem respeito à preocupação sobre como lidar com as mediações envolvidas no processo interativo ao qual, ao menos enquanto projeto, a pesquisa em TV digital devota interesse.

\section{Mudança tecnológica e horizonte de expectativas}

Encarar a TV digital como algo que, a exemplo da TV comercial atual, deva mascarar as mediações envolvidas em sua produção atesta o fenômeno detectado por McLuhan (1969) de aprisionamento do potencial de uma nova tecnologia no padrão cognitivo de uma tecnologia anterior. Isso ocorre, segundo exemplo dado por ele, na tentativa de se apreender o conteúdo veiculado pela televisão da mesma forma como se apreende o conteúdo veiculado num livro.

A leitura da informação na TV, para McLuhan, se dá como a leitura de uma espécie de mosaico, ou seja, através do preenchimento de lacunas de uma informação que o telespectador recebe em forma fragmentária e veloz. Já a leitura do livro, segundo ele, é caracterizada predominantemente pela linearidade e pela possibilidade de retorno constante a um arquivo de informações.

Segundo o autor, as tecnologias surgem com um caráter vanguardista. E, por esta razão, encontram nossas capacidades cognitivas atreladas ao padrão tecnológico anterior. Nesse sentido, a tendência da audiência televisiva, quando do seu surgimento, foi encará-la como algo a ser interpretado dentro do padrão linear da tecnologia do livro. 
A plataforma cognitiva da televisão - dentro de sua potencialidade de oferta de um conteúdo fragmentário, veloz e dotado de uma identidade do tipo quebra-cabeça - é algo que, nem sequer atualmente, foi completamente explorado. Por isso, as experiências mais ousadas, no sentido de intensificar a fragmentaridade e a simultaneidade narrativas da TV, ganharam, no meio acadêmico, o título de expressões pós-modernas da cultura (cf. JAMESON, 1997).

De acordo com McLuhan, o que se chama de pós-moderno é algo que já estaria latente na tecnologia televisiva. Mas, antes mesmo de o DNA da tecnologia televisiva ganhar plena expressão, a galáxia (empregando um termo mcluhiano) das tecnologias multimidiáticas, dentre as quais a TV digital, está se instalando. Apresenta-se então a seguinte situação: um horizonte cognitivo em transição do mundo do papel para o da tela é assaltado pelas expectativas do horizonte cognitivo referente à convergência de plataformas tecnológicas. E o desafio é lidar com os diálogos possíveis entre expectativas e defasagens cognitivas das três potencialidades tecnológicas em jogo: tipografia, TV e convergência multimidiática (incluindo a TV digital).

Ao se retomar o pensamento de McLuhan, o objetivo não é semear a ideia de que o paraíso ou o melhor dos mundos seria aquele em que houvesse uma paridade absoluta entre cognição e desenvolvimento tecnológico. O que se deseja discutir é justamente o contrário: como o exercício de promover o diálogo entre os limites e avanços tanto da tecnologia quanto da cognição (limites não referentes ao intelecto, mas à maneira como se operacionaliza a relação entre ser humano e tecnologia) pode gerar diferentes formatos de expressão e comunicação na atmosfera de convergência de plataformas multimidiáticas?

\section{Interatividade e inclusão social}

Com relação aos níveis de interatividade em ambientes multimidiáticos, tem sido comum os pesquisadores, a exemplo do que fez Sílvio Meira no já mencionado Seminário Televisão Digital, falarem sobre três tipos de universos interativos.

O chamado universo 1.0 refere-se a um nível de interatividade caracterizada pelo ato de adquirir, cujo maior emblema é o download. Na interatividade tipo 2.0, o verbo em destaque é, de acordo com Meira, “participar”, entendido como capacidade reativa. É o caso da enquete, e de outras ferramentas que permitem ao sujeito opinar, mas não interferir. A interferência criadora estaria reservada à interatividade 3.0, cujo verbo seria “inovar". Neste grau de interatividade, encontrado, por exemplo, nas wikis, a audiência - como observou Lauro Teixeira, outro participante do Seminário - cria e transforma conteúdos.

É possível afirmar que estes níveis de interatividade correspondem a posições estratégicas que definem o grau de inclusão dos indivíduos no sistema de comunicação da sociedade em rede, noção desenvolvida por Castells (1999) para designar o momento atual em que a interconexão pautada pelo conhecimento é o principal componente orientador da constituição social. Castells (1999: 396-397) dirá a esse respeito que, o modo como 
se dá a entrada nesse sistema de comunicação - diversificado, multimodal e versátil - define a posição dos sujeitos na sociedade em rede. Em outros termos,

o estabelecimento de barreiras para a entrada nesse sistema de comunicação e a criação de senhas para a circulação e difusão de mensagens pelo sistema representam batalhas culturais cruciais para a nova sociedade nesse novo ambiente histórico, e cujo resultado predetermina o destino dos conflitos mediados por símbolos (CASTELLS, 1999: 461).

De acordo com as idéias de Castells, as pessoas inserem-se no ambiente de convergência multimidiática ou na posição de receptores da interação (interatividade 1.0) ou na de interagentes (2.0 e 3.0). Mas, apesar de a tendência ser comparar essa dupla de conceitos com a de dominantes e dominados, pode-se dizer que os sistemas de comunicação multimidiáticos - a exemplo do que provavelmente será a TV digital permitem aos usuários combinações entre o papel de interagentes e de receptores da interação. Na verdade, resumir a interatividade ao papel do interagente não é o caminho mais viável. Por ser uma relação social, a interatividade pressupõe tendências de conflito e de conciliação dos interesses individual e coletivo, como bem observa Cleveland de Oliveira, também presente no já mencionado Seminário. E, entre conflitos e conciliações, a interatividade se configura oscilando entre interagência e recepção das interações.

\section{Tecnologia e aura}

Uma das tendências quando se está teorizando sobre a TV digital e, conseqüentemente, sobre a convergência de suportes midiáticos, é o impulso de transportar para a plataforma da TV digital os formatos interativos da internet. E, certamente, esta tendência é válida. Como observa Walter Benjamin (1975), o surgimento de novas tecnologias relacionadas à comunicação e à arte, ao mesmo tempo em que transforma o significado das tecnologias existentes até então, guarda resíduos da aura de expressões tecnológicas anteriores.

Não é o momento para se deter no repertório filosófico que Benjamin utiliza para descrever a noção de aura, mas é possível dizer que a aura se refere ao modo como arte e comunicação se coadunam, por meio da técnica, a uma determinada configuração do tempo-espaço, a um determinado hic et nunc (aqui-e-agora). A própria técnica se estrutura na relação dialética com arte, comunicação, tempo e espaço, mesmo contrariando aqueles que desejam ver a técnica como algo neutro, mecânico e absolutamente objetivo.

Benjamin percebeu nas fotografias de nossos entes queridos - os retratos - a presença residual da aura característica da pintura. De maneira semelhante, é possível notar a presença residual da aura do teatro no cinema e do cinema e do teatro na televisão. A reflexão a respeito da aura parece se confirmar no atual contexto da convergência de tecnologias da comunicação e informação. Uma das implicações disto é que os repertórios que a internet vem criando para dar sentido a sua plataforma multimidiática participem da formação da identidade da TV digital. 
Porém, deve-se deixar claro que analisar o modo como os repertórios da internet são apropriados pela TV digital é, nesse momento histórico, uma atividade em grande parte de especulação. Mas esta afirmação não deve ser vista com receio, pois a especulação é um dos principais elementos da construção do saber científico, mesmo que vivamos um período em que seja mais valorizado o saber que revela automaticamente potenciais de instrumentalização mercadológica. É preciso, no entanto, lembrar que grandes desenvolvimentos científicos como a energia nuclear foram gestados por especulações filosóficas vindas de séculos antes. Nesse sentido, mesmo sendo muitas vezes imperceptível, a especulação é uma necessidade da qual os cientistas não podem nem deveriam fugir.

Ao desenvolver um trabalho de especulação sobre a adoção de repertórios de interação da internet pela TV digital, este artigo tem como campo o estudo de estratégias discursivas.

\section{A linguagem da TV digital: entre a regularidade paradigmática e o descentramento sintagmático}

Paiva (2005) descreve como característica da internet o fato de ela oferecer "tecnologias que permitem a criação de textos graficamente mais criativos e novas formas de comunicação e interação que superam limites de tempo e espaço".

Ao se atribuir à interação na internet a capacidade de superação dos limites de tempo e espaço, corre-se o risco de criar o mito de que a convergência multimidiática - relacionada diretamente à TV digital - trabalha no sentido de banir o que é linear e estático.

Como observa Paiva (2005), “a linguagem da internet possibilita a criação de uma inteligência coletiva”. É preciso acrescentar que, além da criação de uma inteligência coletiva, o que está em jogo, na internet e na comunicação multimidiática, é o desenvolvimento e o monitoramento da construção de tal inteligência. Nesse sentido, por mais que se festeje o descentramento, a fragmentaridade, a polifonia e a pluralidade de perspectivas de tempo e de espaço envolvidas no gênero web, deve-se ter em conta que a construção de uma inteligência coletiva envolve regras, e estas pressupõem linearidade. Durante o Seminário TV Digital, a pesquisadora Ana Silvia Médola, inspirada na teoria de Saussure, chamou atenção para o fato de que as plataformas de convergência multimidiática são linguagens. Sendo assim, possuem caráter de imprevisibilidade e atualização constante - características da dimensão sintagmática da linguagem. Em contrapartida, possuem sistematicidade e regularidade - atributos da dimensão paradigmática da linguagem.

Outro ponto bastante discutido durante o Seminário TV Digital foi a questão de como - num futuro que para muitos dos debatedores ainda parece distante e incerto - a TV digital faria para estruturar uma plataforma de comunicação efetivamente bidirecional. Tal plataforma permitiria não somente que a audiência tivesse acesso a esquemas interativos pré-formatados, mas pudesse interferir diretamente na programação que é exibida. Trata-se de um debate que gira em torno de saber como conciliar a existência de uma programação que requer ordem e hierarquização - com a intervenção da audiência, tendendo ao caos e à anarquia. Observa- 
se como nota de fundo desta inquietação a idéia de que a ampliação da interatividade 3.0 poderia tornar inviável a dimensão paradigmática da linguagem televisiva presente tanto na grade de programação das emissoras quanto na roteirização dos programas em particular.

Neste artigo, não se deve esperar encontrar uma resolução para este dilema. Antes, procura-se refletir sobre caminhos possíveis de lidar com o caos - a subversão paradigmática - que a interatividade proporciona. Tomás de Aquino define a ordem (cosmos) como "seqüência lógica, com início e fim" (apud MASSIP, 2001: 115). Ao falar-se sobre o caos, é possível - mesmo levando-se em conta a complexidade filosófica deste termo - seguir o caminho de Ovídio, para quem o caos é o oposto da ordem. Porém, deve-se levar em conta que “atualmente, a diferença entre caos e cosmos recorre dentro das próprias definições de caos e ordem: já não existe nenhum caos puro e nenhuma ordem pura" (MENNINGHAUS, 1996).

\section{Estratégias de gestão do caos interativo: o design de atenção}

O problema da gestão do caos, potencialmente contido nos esquemas de comunicação multidirecionais ou interativos, envolve o que arrisco chamar de design da atenção. Pensar a TV digital como caminho para concretizar a utopia de uma espécie de ágora, em que a audiência pudesse exprimir em alto e bom som seus mais diferentes pontos de vista, é algo que, em médio prazo, talvez não seja impossível, mas inviável. No entanto, a internet já tem demonstrado que é possível a convivência de múltiplas opiniões ou vozes, desde que alocadas em diferentes canais de expressão. Tal trabalho de alocação - ou ergonomia - constituiria o que designo por design da atenção.

Os sites de compartilhamento de vídeos, como o YouTube, são exemplos de que inputs de informação não tem de corresponder, necessariamente, ao conteúdo em exibição ou acessado pela audiência. Tal correspondência equivaleria ao caos. Mas o design da atenção proporcionado pela arquitetura interativa do YouTube é um dos modos possíveis de gerenciar o diálogo entre os canais do caos e da ordem.

O caos, do modo como é representado neste site, é passível de ordenação por meio de sua divisão em canais. Dentre uma infinidade de vídeos disponíveis, o uso de uma ferramenta de busca, por meio de palavraschave, direciona a audiência dentro da dispersão de possibilidades. A filtragem de informações por meio dessa ferramenta de busca pode ser comparada a um mecanismo de sintonia fina em que a audiência interage, configurando ela mesma os canais de acesso à informação que deseja. Isso, claro, em diálogo com limites e fronteiras moldados pela linguagem de programação e pela engenharia informática.

O tipo de design da atenção empregado pelo YouTube poderia, no contexto da TV digital, permitir, por exemplo, que os telespectadores fizessem o upload (o lançamento de informações na web) de vídeos com resumos de programas ou de episódios de séries e novelas. Já é comum no YouTube disponibilizar vídeos cujo conteúdo é a colagem de cenas de um determinado programa de TV. Muitas vezes, o uploader abre mão de diálogos e outros elementos, sobrepondo a estes um fundo musical de sua escolha. Em outros casos, intercala 
as cenas de um determinado programa com cenas de outro e com textos montados por ele em softwares de criação de filmes e vídeos.

Mais do que dar exemplos, o importante é destacar que a TV digital pode proporcionar interatividade baseando-se em designsde atenção semelhantes ao do YouTube, que permite aos interatores construírem seus próprios quadros de memória ou frames $(\mathrm{KOCH}, 1992,1997)$, a partir de informações disponíveis na rede. No caso da TV digital, as diferentes emissoras teriam de se capacitar para dar subsídio para que a audiência, a partir de informações veiculadas pela emissora (conteúdo dos diferentes programas), pudesse criar quadros com colagem de memórias.

Nesta perspectiva, uma das formas de lutar pela audiência será, caso a TV digital adote um design de atenção semelhante ao do YouTube, o desafio de garantir matéria-prima para que os espectadores criem os referidos quadros de memória. A TV digital dará, nesse caso, subsídio para que "a diversidade de interesses, valores e imaginações" participe das "batalhas culturais" ou "conflitos mediados por símbolos" (CASTELLS, 1999: 396-397) ou, numa direção contrária, anestesiará ou gerará a dormência de tais conflitos simbólicos.

Outra maneira de canalizar as informações, a fim de que a interatividade não mergulhe a programação da TV digital no caos, seria a utilização de marcadores do merecimento de atenção. Isso também já vem sendo

utilizado pelo YouTube. Trata-se da avaliação do conteúdo pelo número de estrelas. À medida que a audiência considera um conteúdo veiculado melhor, atribui a ele um número maior de estrelas. Em outros sites, esse mecanismo também é utilizado para se avaliar comentários feitos a respeito de um conteúdo disponibilizado ou respostas formuladas por meio de alguma enquete.

Desta forma, a interatividade é, ao mesmo tempo, incentivada, coordenada e pode ser premiada: quadros de memória, comentários ou respostas com maior cotação estelar podem ser exibidos numa sessão dedicada a destaques da programação. Outra maneira de organizar esta premiação seria estabelecer o acesso a modalidades de expressão, conforme a cotação estelar sobe. Neste caso, o interator, conforme o nível de sua cotação, ganharia o direito de interagir sob diferentes formatos que poderiam ir, por exemplo, do comentário escrito (mural virtual ou twitter) passando pelo comentário em vídeo e indo até a participação ao vivo. Este tipo de hierarquização pode, certamente, variar, conforme os interesses da emissora e do público.

Percebe-se, contudo, que, a fim de não perder sua identidade enquanto gênero a TV, no formato digital, terá de aprender a administrar a existência de diferentes canais dentro de si mesma, afinal possibilitar a interatividade é lidar com a concorrência de formas de expressão diversas, sem se perder de vista que a diversidade implica tanto conflito quanto diálogo.

\section{Comunicação de massa e interatividade: o diálogo entre passividade e atividade}

Castells (1999) afirma que o futuro da televisão é a "descentralização, diversificação e adequação ao público-alvo". Esta adequação ao público alvo, porém, tem ido mais longe do que atender demandas da 
audiência, como descreve o autor. A reflexão, até este ponto, sugere que a TV digital deve lidar com a difícil arte de promover o diálogo entre atividade e passividade da comunicação, no que se refere tanto às emissoras de TV quanto à audiência.

O modelo que tem acompanhado a TV tradicional é o da comunicação de massa (CASTELLS, 1999: 362) em que a audiência é inteiramente passiva e sujeita a um conteúdo nivelado. Com a TV digital, o caminho para se ter uma interatividade que nem seja a passividade mascarada de interação, nem a sujeição ao caos, seria a definição de zonas de atividade e zonas de passividade, tanto para a audiência como para as emissoras. Neste caso, as emissoras de TV, antes plenamente ativas, teriam de definir áreas da programação em que se tornariam passivas à produção de conteúdo pelos telespectadores.

A tela da TV digital - no sentido amplo de gênero textual e no sentido restrito de plataforma de interface - apresentará, possivelmente, zonas de interatividade em diálogo/conflito com zonas de comunicabilidade massiva. Nas zonas de comunicabilidade massiva, como foi dito, predomina a unidirecionalidade da construção e veiculação de mensagens midiáticas, "no sentido tradicional do envio de um número limitado de mensagens a uma audiência homogênea de massa" (Castells, 1999, p.242). Já as zonas de interatividade lidam com a produção segmentada e individualizada. "A audiência visada tende a escolher suas mensagens, assim aprofundando sua segmentação, intensificando o relacionamento individual entre emissor e receptor" (idem).

Um determinado programa pode optar por permanecer dentro da zona de comunicabilidade de massa, fazendo, nesse caso, jus à denominação de "programa". Ou pode permitir-se inserir em zonas de interatividade, abrindo-se a constantes updates ou atualizações. Uma terceira via seria a mescla de momentos em que o programa investe na comunicação de massa e momentos em que investe na interatividade.

A divisão de um meio de comunicação em zonas de interatividade e zonas de comunicação de massa já vem ocorrendo na web. O site do Yahoo, além de seus próprios conteúdos, dispõe de colaboradores cadastrados. A equipe do site monitora continuamente os blogs e sites destes colaboradores, em busca de conteúdo que possa ser veiculado pelo Yahoo. Mas, nesse processo, a identidade dos meios de comunicação dos colaboradores é preservada e, mais do que isso, propagada. Eles não têm seu trabalhado alienado pelo Yahoo. Isto significa uma subversão no próprio funcionamento das relações capitalistas, visto que, nestas, uma das principais características é que o burguês, ao se apropriar do que é produzido por outras pessoas, apaga qualquer vestígio que possa estabelecer relações entre aquele que fez o produto e quem o está comercializando.

Trata-se de uma virada do processo de comunicação de massa. Se, anteriormente, a audiência recebia passivamente o conteúdo produzido pelas emissoras, estas começam a depender ativamente do que é produzido pela audiência, incentivando o protagonismo desta.

É preciso destacar ainda a necessidade de evitar a confusão entre o ser ativo e protagonista e a idéia vaga de um indivíduo que tudo pode. Sílvio Meira, outro dos participantes do Seminário sobre TV Digital, do 
qual vimos falando, estabelece uma relação entre interatividade e colaboração. O protagonista é colaborador. O sentido do verbo colaborar, no entanto, vai além do idealismo e do sentimentalismo. É um gesto que, como dirá Sílvio Meira, envolve um espectro de valores e recursos técnicos, cuja interação é bastante complexa e problemática: curiosidade, confiança, conexões, capacidade e conceito.

\section{O novo papel do comentário na TV digital}

O que a TV representou, antes de tudo, foi o fim da Galáxia de Gutenberg, ou seja, de um sistema de comunicação essencialmente dominado pela mente tipográfica e pela ordem do alfabeto fonético (CASTELLS, 1999: 357).

Mesmo sendo um gênero audiovisual, a televisão tradicional não deixa de manter algo de uma mentalidade tipográfica: a função do comentário no gênero televisivo, assim como na narrativa tipográfica, teve, prioritariamente, o papel de nota de rodapé ou, em outros termos, de apêndice.

Arlindo Machado (2000) observa que a TV incorpora estratégias narrativas de outros meios de comunicação como o teatro e o cinema. Mas, ele destaca que a TV apresenta como sua impressão digital a possibilidade de promover a dialética socrática. Ao dizer isto, o autor se refere ao trabalho do filósofo grego Sócrates de, por meio do diálogo, poder estar sempre reconstruindo noções sobre a verdade e desconstruindo preconceitos. Os debates e mesmo os programas de entrevista, por mais que tentem ficar presos a um roteiro ou sejam engessados por fórmulas ligadas ao apelo do "politicamente correto", apresentam também uma tendência à subversão de tais fórmulas. Marcadamente quando ocorrem ao vivo, estes formatos televisivos são exemplos modernos da estratégia da maiêutica: a arte de uma pessoa estimular a outra a, por meio do confronto de seus próprios erros e contradições, depurar a verdade.

A estratégia do diálogo socrático tende a continuar na TV digital. Mas isso possivelmente acontecerá com uma diferença: o diálogo não se dará somente em torno de uma narrativa principal, mas das múltiplas interferências externas dos telespectadores atuando sobre esta narrativa. Em outras palavras, o confronto de idéias na TV digital possivelmente lidará com a necessidade de dividir a atenção entre narrativa principal e comentário. Nesse caso, o que é considerado principal ou comentário pode variar de acordo com a relação dialética entre eles.

Um exemplo do poder que o comentário vem ganhando no contexto convergência multimidiática é dado por análises de Theo Van Leven sobre os bancos de imagem da internet. Durante o seminário Hipertexto e Tecnologias na Educação: Multimodalidade e Ensino, realizado em setembro de 2008, Van Leven comentou sobre como o próprio status da imagem tem mudado devido à interatividade em plataformas multimidiáticas. Tal mudança está, como veremos, relacionada à ênfase que o comentário tem alcançado. 
Segundo Christian Metz (1974), a imagem é composta por uma dimensão analógica, dada pela visualidade, e um componente codical, dado pelos sentidos que a cultura codifica por meio da imagem. De acordo com Van Leven, este componente analógico vem perdendo o papel de destaque que a cultura vem lhe dando ao longo da história. Isso seria perceptível nos bancos de imagem da internet em que a separação da imagem por categorias - que, muitas vezes, não tem conexão com o componente analógico da imagem - chega até a superar a informação dada pela visualidade no momento em que se está buscando imagens na Rede. As categorias nas quais estão divididas as imagens em tais bancos são, a meu ver, exemplos de como o comentário disputa espaço com a narrativa principal que, historicamente, vinha sendo a narrativa do ver ou, como a denominou Marc Arabyan, durante o seminário Semiótica da Publicidade Visual: a Imagem, o Texto e a Formatação da Página na Comunicação em Papel e na Internet, ocorrido entre 24 e 30 de novembro de 2005: a veitura.

Até na utilização de ferramentas de busca, como o Google, é possível perceber a referida intensificação do papel do comentário. As palavras-chave utilizadas no buscador são comentários que abrem portas para diferentes universos de informação, bem como os diferentes resultados são comentários a respeito do comentário representado pelas palavras-chave da busca. Os buscadores, é bem provável, farão parte da rotina interativa da TV digital.

Na TV digital, as zonas de interatividade têm o potencial de subverter a posição historicamente dada ao comentário, fazendo-o ter importância igual ou superior ao "texto principal". Até mesmo os "textos principais", em última análise, são comentários moldados a partir da montagem de dados proveniente do banco de conhecimentos enciclopédicos $(\mathrm{KOCH}, 1997)$ dos interatores ou memórias grafoaudiovisuais.

\section{O apoio de Hefestos a Hermes: o potencial artístico da interferência na TV digital}

E se é questionável se a beleza duradoura ainda merece ser chamada assim - é certo que a beleza não existe se no seu interior não houver nada digno de ser conhecido. A filosofia não deve tentar negar que redesperta a beleza nas obras. (Walter Benjamin, Alegoria e drama barroco)

No lugar de se preocupar em camuflar as falhas técnicas da interação - os ruídos gerados pelo intercâmbio de palavras, sons, imagens e atitudes - devem-se buscar desenvolver as potencialidades plásticas, poéticas e artísticas dessas falhas. O risco da "tela preta", na TV digital, deve ser não motivo de receio, mas oportunidade de exercício da criatividade. A MTV já mostrou que o estar fora do ar pode fazer parte da programação. Esta emissora já reservou uma faixa de horário para ficar fora do ar: isso por meio de uma tela preta, apresentando só uma frase, convidando a audiência a procurar algo mais útil para fazer como ler um livro.

Vera França reflete sobre o novo perfil atribuído ao deus Hermes: o de deus das comunicações: 
No início era invocado como protetor dos pastores, depois dos viajantes (que construíam estátuas do pequeno deus ao longo dos caminhos). Foi também o patrono dos comerciantes, dos ladrões, dos oradores. É recente esse novo investimento - apesar de que a relação é evidente e imediata; ele era o mensageiro dos deuses, e, com suas pequenas asas, promovia a circulação das mensagens, das intrigas, dos ciúmes e paixões que povoavam o Olimpo (FRANÇA, 1997: 2).

O contexto de digitalização da TV e de convergência das mídias longe de destituir Hermes do seu pedestal, reforça sua imagem enquanto arquétipo da comunicação. Porém, esta posição deve ser dividida com outra divindade olímpica: Hefestos. Este deus (BULFINCH, 1965), o divino artífice, segundo a mitologia, cria obras de arte tão perfeitas que são capazes de adquirir vida. A figura de Hefestos é paradoxal, pois sendo ele o mais feio dos deuses, forjava peças de incomparável beleza. Ele representa, alegoricamente, um dos principais potenciais da TV digital: o desafio de estar, constantemente, fazendo arte a partir da feiúra que a constituirá. Feiúra esta representada por uma programação disposta a abrir espaço à interatividade, entendida enquanto interferência. Mas, assim como nossa época tem aprendido a enxergar no lixo a renovação e a obra de arte, é possível também pensar no fenômeno da reciclagem - encarada não só como reaproveitamento, mas como reutilização criativa - como algo que pode ser aplicado ao rúdo comunicacional gerado pelo processo da interatividade.

\section{Entre o efeito-realidade e a metalinguagem: o dilema entre aceitar ou enfrentar o condicionamento}

\section{ideológico}

Como se viu, no contexto da TV digital e da convergência multimidiática ocorre uma tensão entre a passividade - relativa à zona de comunicabilidade massiva - e a atividade referente às zonas de interatividade. Em termos políticos, esta tensão reflete o dilema entre se deixar sujeitar ao condicionamento exercido pelo aparelho ideológico dos meios de comunicação, ou enfrentar essa tendência de condicionamento, expondo as fraturas e contradições do aparelho ideológico.

As teorias da comunicação, no início de seu desenvolvimento, cujo um dos marcos é a obra de Lasswell Propaganda techniques in world war, de 1927, defendiam a idéia de que a relação entre os meios de comunicação e o ser humano era mediada pela manipulação. Porém, como bem observa Carolina Figueiredo, o público sofre influência de conteúdos ideológicos dos meios de comunicação,

não por ser manipulável, mas por necessitar deles para 'caber' nas relações sociais que o circundam e exercer seu papel duplo de produtor consumidor. Assim, embora não sejam impositivos, os meios de comunicação oferecem aos indivíduos uma possibilidade fantástica, a de se inserirem socialmente, serem socialmente aceitos e produzirem sem conflitos. (FIGUEIREDO, 2007: 235). 
No entanto, apesar da forte tendência do ser social de aceitar o condicionamento a fim de "caber" nas relações sociais, existe também a tendência de rebeldia contra o ele quando este mesmo ser social sente não caber nos condicionamentos socialmente construídos.

No que se refere à oscilação dos interatores entre formas de expressão lineares e não-lineares, representadas por diversas combinações e sinestesias entre palavra escrita, som e vídeo, tal oscilação pode ser entendida como decorrente do conflito entre aderir ao ou repelir o roteiro de condicionamento dos diferentes aparelhos ideológicos. As batalhas simbólicas no contexto multimidiático, às quais se refere Castells (1999), refletem a posição tensa e ambígua de indivíduos que buscam criar imagens-tempo capazes de representar a sujeição ou o enfrentamento dos condicionamentos sociais, a começar por aqueles relativos às multimodalidades da linguagem.

Nesse caso, não nos referimos mais somente aos discursos condicionadores difundidos pela mídia, mas também aos discursos dos demais aparelhos, a exemplo da Escola, da Igreja e dos diferentes ambientes de trabalho (ALTHUSSER, 1980; FIGUEIREDO, 2007). Contudo, como lembra Castells (1999), a mídia atual caracteriza-se por infiltrar-se em toda a tessitura social e, portanto, a influência exercida pelo aparelho ideológico dos meios de comunicação dialoga o tempo inteiro com a influência dos demais aparelhos.

A TV tradicional, majoritariamente inserida no esquema da comunicação de massa, trabalhou a geração do efeito-realidade. A geração de tal efeito está diretamente relacionada ao poder simbólico, "um poder de construção da realidade que tende a estabelecer sentido imediato do mundo (em particular do mundo social), através dos habitus que dissemina" (FIGUEIREDO, 2007: 241) (1).

$\mathrm{O}$ que deve ocorrer, num contexto de interatividade proporcionado pela TV digital (e que já vem sendo gerado na web), é que a metalinguagem e o efeito-realidade - as já mencionadas estratégias enunciativas da TV - brigarão por espaço ao mesmo tempo em que tentarão forjar momentos de união, mesmo ignorando o paradoxo residente nesta tentativa. E o conflito entre efeito-realidade e metalinguagem está intimamente relacionado à tensão entre forças sócias pró-estabelecimento e pró-destituição do habitus.

A comunicação na sociedade em rede parece não se contentar entre a opção ou, ao menos, a ilusão de fazer uma opção radical entre as alternativas que a história consagrou até a última década do século XX: a adesão ao sistema ou o desvelar das ideologias que permitem ao sistema perpetuar sua dominação. Adota-se uma terceira via, jogando-se com as possibilidades de expor a trama do habitus ou contribuir para que esta trama preserve sua efetividade invisível. E nesse jogo ora ganham destaque as utopias, ora as distopias.

Na televisão tradicional, as alternativas apresentadas são o mascaramento ou o desmascaramento dos mecanismos de mediação envolvidos na representação da realidade. A $T V$ digital, além desta preocupação, lidará, possivelmente, com a opção entre $o$ mascaramento ou desmascaramento de expressões da interatividade. Além disso, outra preocupação relativa às estratégias enunciativas da TV digital poderá estar na escolha entre o mascaramento e o desmascaramento das mediações envolvidas no próprio processo interativo. 


\section{Considerações finais}

Walter Benjamin observa, em um de seus textos de maior destaque ("Sobre o conceito de História"), que a intensificação da democracia não deve desviar a atenção das pessoas do fantasma dos totalitarismos que assombram o imaginário do ser humano moderno, marcado tanto pela utopia da comunhão entre razão e liberdade, quanto por um desejo de administrar e controlar a vida em todas as instâncias. Benjamin percebeu, por exemplo, como a Alemanha, mesmo estando num período democrático (República de Weimar) no período imediatamente anterior à Segunda Guerra deixou-se influenciar pelo ideário nazista.

Este preâmbulo tem em vista chamar atenção para o fato de que fantasmas de índole totalitarista podem assombrar a comunicação em rede representada pelas diversas convergências midiáticas, dentre as quais a TV Digital, apesar de estarem aptas para elevar exponencialmente a participação democrática. $\mathrm{O}$ que foi chamado de cotação estelar pode ajudar a dosar o caos na interatividade, mas será um desafio do novo contexto de intensificação da comunicação interativa impedir que os mecanismos de avaliação das contribuições dos interatores não transformem os meios de comunicação em meios de apartheid ou de geração de guetos.

A interatividade, distribuída por diferentes canais de expressão, tem como papel, dentro de parâmetros democráticos, permitir que tanto as opiniões majoritárias quanto as minoritárias possam se expressar. Democraticamente, o saudável é que ambos os tipos de opinião possam ter chance de se expressar nos diferentes canais oferecidos, evitando-se que determinados tipos de conteúdos fiquem confinados a um determinado canal de expressão, seja ele o texto escrito ou o texto áudio-visual.

A democracia, num contexto de potencialização da interatividade, não será expressa por meio da possibilidade de todos terem voz, mas de a sociedade lutar para repartir com eqüidade os momentos de ter voz e de se ficar em silêncio. Mas tal eqüidade não está relacionada somente à beleza e ao vigor da utopia. A repartição justa entre o ter voz e o ficar em silêncio implica a coragem de enfrentar a condição de invisibilidade à qual estamos sujeitos quando estamos fora da "lista dos dez mais", tão característica da socialização na Rede. Seria preciso também coragem para perceber que a visibilidade na Rede é mais uma espécie de verão da formiga - uma preparação para os invernos rigorosos da não-visibilidade - do que a euforia da cigarra. E, nos dois casos mencionados, acreditamos que ter coragem significa nada mais do que administrar o medo.

Ao se falar na dosagem do caos, por meio da gestão da interatividade, não se tem em mente a idéia de que é possível eliminar o caos. Conforme Hegel (apud MARCUSE, 1978), não se pode conhecer a razão sem um diálogo sincero com o caos. A interatividade, ao buscar dar plasticidade às mais diversas visões de mundo, tem a possibilidade de promover esse diálogo sincero com o caos. Isso significa afastar-se do caminho que a cultura ocidental vem trilhando: de eleger determinadas concepções como estandartes da ordem, sem pensar em maneiras de lidar com as visões alternativas, comumente condenadas ao rótulo precipitado de caos, ao qual, de maneira simplista, se confere pejo. Lidar com o alternativo implica não o trânsito entre diferentes 
paradigmas legitimados pela autoridade (a exemplo das escolas de pensamento), mas sim dar subsídio para que o não-oficial possa se expressar. Afinal, os discursos marginais tendem a assumir a aparência de completo caos quando não encontram canais para se expressarem artisticamente, para se textualizarem, por meio da combinação de som, imagem e escrita. A tendência ao completo caos é decorrente da pressão que os discursos subjugados sofrem - perante a opulência do status quo - e da tentativa de recorrer ao impacto para tentarem se fazer ouvir.

$\mathrm{Na}$ tese nove do já mencionado texto de Benjamin, "Sobre o conceito de História", ele faz uma leitura alegórica de um quadro de Paul Klee, chamado Angelus Novus:

Representa um anjo que parece querer afastar-se de algo que ele encara fixamente. Seus olhos estão escancarados, sua boca dilatada, suas asas abertas. O anjo da história deve ter esse aspecto. Seu rosto está dirigido para o passado. Onde nós vemos uma cadeia de acontecimentos, ele vê uma catástrofe dispersa a nossos pés. Ele gostaria de deter-se para acordar os mortos e juntar os fragmentos. Mas uma tempestade sopra do paraíso e prende-se em suas asas com tanta força que ele não pode mais fechá-las. Essa tempestade o impele irresistivelmente para o futuro, ao qual ele vira as costas, enquanto o amontoado de ruínas cresce até o céu. Essa tempestade é o que chamamos progresso.

O entulho que se amontoa e que forma uma tempestade, empurrando o anjo para o futuro é, para Benjamin, a representação alegórica do progresso que não se importa com os mortos que deixa para trás. O caos é tanto maior quanto maior é o acúmulo das versões da história sufocadas pelo progresso. Mas, é possível cultivar relativo otimismo, pois, a intensificação da comunicação interativa, que há de ser desenvolvida inclusive pela TV digital, permite que o Anjo da História consiga não só ajuntar como dar expressividade aos cacos que o progresso empurra para o abismo do completo caos. Uma interatividade marcada pela eqüidade permite que o progresso e o caos se desenvolvam de maneira sustentável, devolvendo o equilíbrio (mesmo que instável) ao Anjo da História.

\section{Notas}

(1) Carolina Figueiredo retoma o conceito de habitus formulado por Bourdieu: "Sistema de disposições duráveis e transferíveis que, integrando todas as experiências passadas, funciona a cada momento como uma matriz de percepções, apreciações e ações".

\section{Referências Bibliográficas}

BENJAMIN, Walter. "Sobre o conceito de História". In: Obras Escolhidas I: Magia e técnica, Arte e Politica. São Paulo: Brasiliense, 1996. . “A obra de arte na época de suas técnicas de reprodução". In: Textos escolhidos. Seleção de Loparic, Zeljko e Fiori, Otília B. São Paulo: Abril Cultural, 1975 (Os Pensadores).

BULFINCH, Thomas. O livro de ouro da mitologia. Tradução de David Jardim Jr. Tecnoprint, 1965. 
CASTELLS, Manuel. A sociedade em rede. Tradução de Roneide Venâncio Majer. São Paulo: Paz e Terra, 1999.

FECHINE, Yvana. "O Núcleo Guel Arraes e sua 'pedagogia dos meios””. In: Revista da Associação Nacional dos Programas de Pós-Graduação em Comunicação - E-Compós. Abril de 2007. Disponível em: Www.compos.com.br/e-compos.

FIGUEIREDO, Carolina Dantas. "Poder e Comunicação: um breve debate sobre a questão do poder nos meios de comunicação de massa”. In: Revista ECO-PÓS/UFRJ - Programa de Pós-Graduação em Comunicação e Cultura da Escola de Comunicação, n.2. Rio de Janeiro: ECO/UFRJ, 2007.

FRANÇA, Vera Regina Veiga. "Reflexões sobre a Comunicação: esse estranho objeto". In: Geraes - Revista da Comunicação Social, n. 48, 1997.

JAMESON, Fredric. Pós-modernismo ou a lógica cultural do capitalismo tardio. Tradução de Maria Elisa Cevasco. São Paulo: Ática, 1996.

KOCH, Ingedore G. V. A inter-ação pela linguagem. São Paulo: Contexto, 1992 O texto e a construção dos sentidos. São Paulo: Contexto, 1997.

MCLUHAN, Marshall e FIORE, Quentin. O meio são as massa-gens. Tradução de Ivan Pedro de Martins. Rio de Janeiro: Record, 1969.

MASIP, Vicente. História da filosofia ocidental. São Paulo: EPU, 2001.

MACHADO, Arlindo. A televisão levada a sério. São Paulo: Senac, 2000.

MENNINGHAUS, Winfried. "Mitologia do caos e do romantismo na modernidade". In: Estudos Avançados, n.27. São Paulo, 1996. Disponível em: http://www.scielo.br/scielo.php?pid=S0103$40141996000200008 \&$ script=sci_arttext.

METZ, Christian. A análise das imagens. Tradução de Luís Costa Lima e Priscila Viana de Siqueira. Petrópolis: Vozes, 1974.

PAIVA, Vera Lucia Menezes de Oliveira e. Entrevista publicada na Letra Magna: Revista Eletrônica de Divulgação Científica em Língua Portuguesa, Lingüística e Literatura, n.03, 2005. 